\title{
Genetic factors in precocious puberty
}

\author{
Young Suk Shim, MD, Hae Sang Lee, MD, PhD, Jin Soon Hwang, MD, PhD
}

Department of Pediatrics, Ajou University Hospital, Ajou University School of Medicine, Suwon, Korea

Pubertal onset is known to result from reactivation of the hypothalamic-pituitary-gonadal (HPG) axis, which is controlled by complex interactions of genetic and nongenetic factors. Most cases of precocious puberty (PP) are diagnosed as central PP (CPP), defined as premature activation of the HPG axis. The cause of CPP in most girls is not identifiable and, thus, referred to as idiopathic CPP (ICPP), whereas boys are more likely to have an organic lesion in the brain. ICPP has a genetic background, as supported by studies showing that maternal age at menarche is associated with pubertal timing in their offspring. A gain of expression in the kisspeptin gene (KISS1), gain-offunction mutation in the kisspeptin receptor gene (KISS1R), loss-of-function mutation in makorin ring finger protein 3 (MKRN3), and loss-of-function mutations in the delta-like homolog 1 gene (DLK1) have been associated with ICPP. Other genes, such as gamma-aminobutyric acid receptor subunit alpha-1 (GABRA1), lin-28 homolog B (LIN28B), neuropeptide Y (NPYR), tachykinin 3 (TAC3), and tachykinin receptor 3 (TACR3), have been implicated in the progression of ICPP, although their relationships require elucidation. Environmental and socioeconomic factors may also be correlated with ICPP. In the progression of CPP, epigenetic factors such as DNA methylation, histone posttranslational modifications, and noncoding ribonucleic acids may mediate the relationship between genetic and environmental factors. CPP is correlated with short- and long-term adverse health outcomes, which forms the rationale for research focusing on understanding its genetic and nongenetic factors.

Key words: Central precocious puberty, DLK1 gene, KISS1 gene, KISS1R gene, MKRN3 gene

\section{Key message}

- Mutations in the kisspeptin (KISS1), kisspeptin receptor (KISS1R), makorin ring finger protein 3 (MKRN3), and deltalike homolog 1 (DLK1) genes are associated with idiopathic central precocious puberty (ICPP).

- A few genes related to pubertal onset have been implicated in ICPP.
- Epigenetic factors such as DNA methylation, histone posttranslational modifications, and noncoding ribonucleic acids may be related to ICPP.

\section{Introduction}

Puberty is the transitional period from childhood to adulthood during which an individual matures gradually, develops secondary sexual characteristics, and becomes physically fertile. From a psychosocial perspective, a person develops cognitive function, self-reflection, and moral values during puberty. Because the mechanisms of pubertal development have not been fully elucidated, it remains a great mystery of science. During the fetal and neonatal periods, the hypothalamicpituitary-gonadal (HPG) axis is active; however, in the period before pubertal onset, this activity is repressed and the HPG axis becomes quiescent. ${ }^{2)}$ The axis is then reactivated during pubertal onset, which leads to pulsatile gonadotropin-releasing hormone $(\mathrm{GnRH})$ secretion. $\mathrm{GnRH}$ is regulated by activators such as kisspeptin as well as inhibitors of the HPG axis. ${ }^{2)}$ In brief, GnRH secretion is results from increases in activators, including kisspeptin produced by kisspeptin, neurokinin $\mathrm{B}(\mathrm{NKB})$, and dynorphin (KNDy) neurons. ${ }^{3)} \mathrm{NKB}$ and its receptor (neurokinin receptor 3, NK3R) play a role in the upstream regulation of kisspeptin.

The kisspeptin signaling pathway through kisspeptin receptors (KISS1R) on GnRH neurons controls pulsatile GnRH release. $\mathrm{GnRH}$ secretion leads to increases in luteinizing hormone and follicle-stimulating hormone from the pituitary, which results in the activation of sex steroid production (testosterone in males, estrogen and progesterone in females) and the production of sperm and mature oocytes. Activation of the HPG axis results in the progression of puberty, including breast development, pubic hair growth, and menstruation in girls and testicular enlargement, pubic hair growth, an increase in penile length, and voice changes in boys. ${ }^{4}$ The average age at pubertal onset is $10-11$ years in girls and $11-12$ years in boys. ${ }^{4)}$

\footnotetext{
Corresponding author: Jin Soon Hwang MD, PhD. Department of Pediatrics, Ajou University Hospital, Ajou University School of Medicine, 164 World cup-ro, Yeongtong-gu, Suwon 16499, Korea 


\begin{tabular}{|lll|}
\hline Gene & Protein & Relation to CPP \\
\hline KISSI & Kisspeptin & Gain of expression in KISS1 can lead to CPP. \\
\hline KISSIR & KISS1 receptor & Gain-of-function mutation in KISS1R can lead to CPP. \\
\hline MKRN3 & MKRN3 & Loss-of-function mutation in MKRN3 can lead to CPP. \\
\hline DLK1 & Delta-like homolog 1 & Loss-of-function mutation in DLK1 can lead to CPP. \\
GABRA1 & Gamma amino butyric acid A1 receptor $\alpha-1$ subunit & Loss of function mutations or polymorphisms in GABRAI might \\
\hline LIN28B & Lin 28 homolog B & be related to CPP. \\
\hline NPYRI & Neuropeptide Y (NPY) & Polymorphism in may be related to CPP. \\
\hline TAC3 & Neurokinin B (NKB) & NPYRI mutation or polymorphism may be related to CPP. \\
\hline TACR3 & Neurokinin receptor & TAC3 mutation or polymorphism may be related to CPP. \\
\hline
\end{tabular}

Graphical abstract

\section{Precocious puberty}

\section{Definition}

Based on this normal pubertal timing, precocious puberty (PP) has been defined as breast development before the age of 8 years in girls and testicular enlargement $\geq 4 \mathrm{~mL}$ before the age of 9 years in boys. ${ }^{5)}$ Concern has been raised regarding modification of the definition of PP because of the downward secular trend of pubertal onset. A Korean study showed a downward secular trend in menarche. The estimated mean age at menarche in girls born between 1986 and 1995 was 13.10 years, whereas that in girls born between 1980 and 1985 was 13.79 years. ${ }^{6}$ The mean menarcheal age, 13.0 years for girls born in 1988 , decreased to 12.6 years for girls born in 2003 in a very recent study. ${ }^{7}$ These findings are consistent with those of other Western countries. The estimated ages at menarche were 13.42 and 13.13 years for girls born in the 1991 and 2006 cohorts, respectively.

On the other hand, recent studies have suggested that the age at menarche is not advanced or slightly advanced compared to that of a previous report, whereas the age at breast development was observed earlier in girls evaluated in the mid-2000s. $\left.{ }^{8}\right)$ The earlier timing of breast development in girls seems to be independent of the HPG axis, but it might be attributed to other potential mechanisms such as endocrine disruptors and nutritional effects. The earlier timing of breast development also affected the definition of Tanner stage, which classified breast development into 5 stages using inspection but not palpation. ${ }^{9)}$ A significant decrease in age at menarche has been observed in developing countries, which may be related to increased socioeconomic status and increased body mass index (BMI). ${ }^{10)}$ In addition, controversy persists regarding whether it is valid to modify the definition of PP considering the relationship between early age at menarche and adverse health outcomes in adults. To date, the traditional definition of PP has been applied in clinical settings in Korea and other countries.

\section{Impact of PP on health outcomes}

At the time of a PP diagnosis, the main concerns are early menarche in girls, short adult stature due to early skeletal maturation, and psychosocial problems. However, the early timing of pubertal onset may increase an individual's long-term health risks. Evidence indicates that early menarcheal age is related to an increased risk of obesity and its related diseases (hypertension and type 2 diabetes mellitus), cardiovascular disease, and mortality. ${ }^{11)}$ An early age at menarche has been suggested to increase a woman's risk of breast cancer. ${ }^{12)}$ Early exposure to sex steroids, especially estrogen, plays a significant role in this relationship during the initial stages of breast development and throughout the reproductive years. In addition, PP can affect future psychosocial outcomes, including internalizing problems such as depression, anxiety, bulimia, and excessive psychosomatic symptoms as well as externalizing symptoms such as substance abuse, smoking, bullying, and truancy. ${ }^{13)}$

\section{CPP and genetics factors}

PP includes central PP (CPP, with a GnRH-dependent mechanism of development) and peripheral PP (PPP, with a GnRHindependent mechanism of development). CPP is defined as premature activation of GnRH release, whereas PPP is defined as the development of secondary sexual characteristics independent of GnRH pulsatile secretion. PPP, which is related to exogenous sex steroids, autonomous ovarian cysts, or human chorionic gonadotropin, is less frequent than CPP. ${ }^{14)}$ Approximately 80\% of PP cases are estimated to be $\mathrm{CPP}{ }^{14)}$ and CPP occurs more frequently in girls than in boys. ${ }^{14)}$ Organic brain diseases such as hypothalamic hamartoma, suprasellar arachnoid cysts, and hydrocephalus may lead to CPP, and approximately one-third of all CPP cases are considered related to organic brain lesions. ${ }^{15)}$ The cause of CPP in most girls is not identifiable and called idiopathic CPP (ICPP). ${ }^{15}$ )

Approximately $50 \%$ of boys with CPP have organic lesions in the brain. ${ }^{15)}$ However, a recent study evaluated whether boys with CPP have a lower prevalence of brain lesions than previously 
reported. ${ }^{16)}$ Other studies reported an increased prevalence of ICPP. ${ }^{17)}$ Genetic factors may be involved in the diagnosis of ICPP in both girls and boys. In addition, recent advances have enabled the identification of genetic predispositions in girls and boys with $\mathrm{CPP}$ versus those with normal puberty. Recent studies of genetics and CPP are summarized in Table 1. Therefore, this review focuses on the genetic and epigenetic factors related to CPP.

\section{Genetic factors associated with ICPP}

The progression of puberty is mediated by a complex control mechanism between genetic and nongenetic factors, such as environmental, nutritional, and epigenetic factors. ${ }^{18)}$ The genetic background of pubertal onset is supported by studies showing that maternal age at menarche is associated with pubertal timing in her offspring. ${ }^{19)}$ The impact of genetic factors on pubertal timing is also supported by twin studies indicating that a higher correlation for milestones of pubertal development was observed in monozygotic twins than in dizygotic twins. ${ }^{20)}$ Table 2 shows the genes related to CPP progression. Of these genes, only 4 (KISS, KISS1R, MKRN3, and DLK1) have been confirmed to play a role in patients diagnosed with CPP to date. Other genes have been implicated in ICPP, but their relationship remains to

Table 1. Recent genetic studies of central precocious puberty (CPP)

\begin{tabular}{|c|c|c|c|c|c|}
\hline Study & Year & Content & Field & Summary & Subject \\
\hline Li et al. ${ }^{100)}$ & 2021 & Epigenetic regulation & Epigenetics & $\begin{array}{l}\text { Three Poly(A)-binding proteins (PABPs) family members, including PABPC1, } \\
\text { PABPC3 and PABPC4, are identified as novel interacting partners and } \\
\text { substrates for E3 ligase MKRN3. }\end{array}$ & Animal \\
\hline Seraphim et al. ${ }^{101)}$ & 2021 & MKRN3 & Genetics & $\begin{array}{l}\text { Premature activation of the reproductive axis due to loss-of-function } \\
\text { mutations of MKRN3 is clinically indistinct from ICPP. }\end{array}$ & Human \\
\hline Canton et al. ${ }^{102)}$ & 2021 & Epigenetic defects & Epigenetics & $\begin{array}{l}\text { Chromosome } 14 q 32.2 \text { disruption indicates the loss of imprinting of } D L K 1 \text { as } \\
\text { a probable mechanism of CPP. }\end{array}$ & Human \\
\hline Varimo et al. ${ }^{103)}$ & 2020 & MKRN3 & Genetics & Two novel MKRN3 mutations are identified in 3 CPP patients. & Human \\
\hline Montenegro et al. ${ }^{104)}$ & 2020 & $D L K 1$ & Genetics & Loss-of-function mutations of $D L K 1$ represent a rare cause of CPP. & Human \\
\hline Lee et al. $^{52)}$ & 2020 & $D L K 1$ & Genetics & DLK1 mutations are a relatively rare cause of idiopathic CPP. & Human \\
\hline Abreu et al. ${ }^{105)}$ & 2020 & MKRN3 & Genetics & MKRN3 acts to prevent puberty initiation. & Animal \\
\hline Pagani et al. ${ }^{106)}$ & 2020 & MKRN3 and KISS1R & Genetics & $\begin{array}{l}\text { Variants in KISS } 1 R \text { and MKRN3 genes might be inducible factors in the } \\
\text { pathogenesis of CPP. }\end{array}$ & Human \\
\hline Li et al. ${ }^{107)}$ & 2020 & $\begin{array}{l}\text { KISS1/KISS1R } \\
\text { Pathway }\end{array}$ & Genetics & $\begin{array}{l}\text { Polymorphism in KISS1 (rs5780218), PLCB1 (rs708910) gene increases the } \\
\text { risk of CPP. }\end{array}$ & Human \\
\hline Chen et al. ${ }^{108)}$ & 2019 & $M K R N 3$ and $D L K 1$ & Genetics & $\begin{array}{l}\text { Variants of MKRN3 and DLK1 are relatively uncommon in Chinese CPP } \\
\text { patients. }\end{array}$ & Human \\
\hline Fanis et $_{\text {al. }}{ }^{93)}$ & 2019 & MKRN3 & Genetics & $\begin{array}{l}\text { Three novel mutations in the promoter and 5'-UTR regulatory regions of the } \\
\text { MKRN3 gene are related to CPP }\end{array}$ & Human \\
\hline Su et al. $^{109)}$ & 2019 & DNA methylation & Epigenetics & $\begin{array}{l}\text { Early puberty is induced by maternal exposure to BPA during pregnancy } \\
\text { through the increased methylation levels of hypothalamus PCG gene (Eed, } \\
\text { Ezh) in female offspring. }\end{array}$ & Animal \\
\hline Suzuki et al. ${ }^{110)}$ & 2019 & MKRN3 & Genetics & MKRN3 defects are rare in Asian populations & Human \\
\hline Ghaemi et al. ${ }^{111)}$ & 2019 & $K I S S 1 R$ & Genetics & Polymorphism in GPR54 gene is related to familial central precocious puberty & Human \\
\hline Bessa et al. ${ }^{94)}$ & 2018 & Methylome profiling & Epigenetics & $\begin{array}{l}\text { Changes in methylation of several zinc finger (ZNF) genes appear to be a } \\
\text { distinct epigenetic modification underlying the initiation of human puberty. }\end{array}$ & Human \\
\hline Gomes et al. ${ }^{51)}$ & 2019 & $D L K 1$ & Genetics & Loss-of-function mutations of DLK1 are a definitive cause of familial CPP. & Human \\
\hline Yi et al. ${ }^{112)}$ & 2018 & MKRN3 and LIN28B & Genetics & MKRN3 SNP rs12441827 is related to precocious puberty in Korean boys. & Human \\
\hline Jeong et al. $^{113)}$ & 2019 & $\begin{array}{l}\text { Luteinizing hormone } \\
\text { receptor (LHCGR) }\end{array}$ & Genetics & $\begin{array}{l}\text { LHCGR gene polymorphisms do not appear to be a major causative factor for } \\
\text { non-classic CPP. }\end{array}$ & Human \\
\hline Jeong HR, et al. ${ }^{114)}$ & 2017 & MKRN3 & Genetics & MKRN3 mutation is uncommon in Korean patients with familial CPP. & Human \\
\hline Grandone et al. ${ }^{115)}$ & 2017 & $\begin{array}{l}\text { MKRN3, DLK1, and } \\
\quad K C N K 9\end{array}$ & Genetics & $\begin{array}{l}\text { The prevalence of MKRN3 mutations in our cohort is similar to previous } \\
\text { results. Mutations in DLK1 and KCNK9 do not seem to be a common cause } \\
\text { of CPP. }\end{array}$ & Human \\
\hline Chen et al. ${ }^{116)}$ & 2017 & LIN28B & Genetics & Polymorphism in LIN28B is associated with girls with CPP. & Human \\
\hline Dauber et al. ${ }^{50)}$ & 2017 & $D L K 1$ & Genetics & Genomic defect in DLK1 is associated with isolated familial CPP & Human \\
\hline Ortiz-Cabrera et al. ${ }^{117)}$ & 2017 & MKRN3 & Genetics & MKRN3 is the most frequent genetic cause of familial ICPP & Human \\
\hline Oh et al. ${ }^{32)}$ & 2017 & $K I S S 1 R$ & Genetics & Variants of the $K I S S 1 R$ gene can be related to CPP. & Human \\
\hline Simsek et al. ${ }^{118)}$ & 2017 & MKRN3 & Genetics & MKRN3 mutation is related to CPP. & Human \\
\hline $\begin{array}{l}\text { Dimitrova-Mladenova } \\
\text { et al. }{ }^{119)}\end{array}$ & 2017 & MKRN3 & Genetics & Mutation in MKRN3 may be aymptomatic in boys & Human \\
\hline Hu et al. ${ }^{120)}$ & 2017 & LIN28B & Genetics & Polymorphism in LIN28B may contribute to CPP susceptibility & Human \\
\hline
\end{tabular}

PABP, poly(A) binding protein; PABPC1,3,4, poly(A) binding protein cytoplasmic 1,3,4; MKRN3, makorin ring finger protein 3 gene; ICPP, idiopathic central precocious puberty; CPP, central precocious puberty; DLK1, delta-like homolog 1 gene; KISS1R, kisspeptin receptor gene; KISS1, kisspeptin gene; PLCB1, phospholipase $\mathrm{C}$ beta 1; BPA, bisphenol A; LHCGR, luteinizing hormone receptor; LIN28B, lin-28 homolog B gene; KCNK9, potassium channel subfamily K member 9 
Table 2. Possible genes related to central precocious puberty (CPP)

\begin{tabular}{|c|c|c|c|}
\hline Gene & Protein & Action of mechanism & Relation to CPP \\
\hline KISS1 & Kisspeptin & $\begin{array}{l}\text { Kisspeptin which binds to KISS1 receptor is related to pulsatile } \\
\text { gonadotropin-releasing hormone }(\mathrm{GnRH}) \text { release. }\end{array}$ & Gain of expression in KISS1 can lead to CPP. \\
\hline KISS1R & KISS1 receptor & $\begin{array}{l}\text { KISS1 receptor, G-protein-coupled receptor that binds to } \\
\text { kisspeptin is related to pulsatile GnRH release. }\end{array}$ & $\begin{array}{l}\text { Gain-of-function mutation in KISS1R can lead } \\
\text { to CPP. }\end{array}$ \\
\hline MKRN3 & MKRN3 & $\begin{array}{l}\text { MKRN3 plays a role in ubiquitination which means intracellular } \\
\text { degradation that is related to intracellular degradation }\end{array}$ & $\begin{array}{l}\text { Loss-of-function mutation in MKRN3 can lead } \\
\text { to CPP. }\end{array}$ \\
\hline$D L K 1$ & Delta-like homolog 1 & $\begin{array}{l}\text { DLK1 plays an inhibitory role in GnRH release via inhibiting } \\
\text { Notch signaling which needs to kisspeptin secretion. }\end{array}$ & $\begin{array}{l}\text { Loss-of-function mutation in DLK1 can lead } \\
\text { to CPP. }\end{array}$ \\
\hline GABRA1 & $\begin{array}{l}\text { Gamma amino butyric acid } \\
\text { A1 receptor a-1 subunit }\end{array}$ & $\begin{array}{l}\text { GABA-A receptor a-1 subunit that binds to GABA may inhibit } \\
\text { GnRH release. }\end{array}$ & $\begin{array}{l}\text { Loss-of-function mutations or polymorphisms } \\
\text { in GABRA1 might be related to CPP. }\end{array}$ \\
\hline LIN28B & Lin 28 homolog B & $\begin{array}{l}\text { Unknown, Homolog of } C \text {. elegans protein may play in } \mathrm{GnRH} \\
\text { secretion }\end{array}$ & Polymorphism in may be related to CPP. \\
\hline NPYR1 & Neuropeptide Y (NPY) & $\begin{array}{l}\text { NPY receptor } 1 \text { that binds NYP may have an inhibitory effect on } \\
\text { GnRH pulse generator activity. }\end{array}$ & $\begin{array}{l}\text { NPYR1 mutation or polymorphism may be } \\
\text { related to CPP. }\end{array}$ \\
\hline TAC3 & Neurokinin B (NKB) & $\begin{array}{l}\text { NKB that binds to Neurokinin receptor } 3 \text { may play a role in } \\
\text { GnRH release. }\end{array}$ & $\begin{array}{l}\text { TAC3 mutation or polymorphism may be } \\
\text { related to CPP. }\end{array}$ \\
\hline TACR3 & Neurokinin receptor & $\begin{array}{l}\text { Neurokinin receptors, which is G protein-coupled receptor that } \\
\text { bind to neurokinin B may play a role in GnRH release. }\end{array}$ & $\begin{array}{l}\text { TACR3 mutation or polymorphism may be } \\
\text { related to CPP. }\end{array}$ \\
\hline
\end{tabular}

$D L K 1$, delta-like homolog 1 gene; GABRA1, gamma-aminobutyric acid receptor subunit alpha 1 gene; KISS1, kisspeptin gene; KISS1R, kisspeptin receptor gene; LIN28B, lin-28 homolog B gene; MKRN3, makorin ring finger protein 3 gene; NPYR, neuropeptide Y gene; TAC3, tachykinin 3 gene; TACR3, tachykinin receptor 3 gene; GABA, gamma-aminobutyric acid.

be elucidated.

\section{Kisspeptin gene (KISS 1)}

Kisspeptin, which is encoded by the KISS1 gene, is a key factor related to pubertal onset. This peptide hormone is found in a few tissues in the human body, such as the hypothalamus, adrenal gland, and pancreas. ${ }^{21)}$ Kisspeptin acts as a ligand for the kisspeptin receptor, which is encoded by the KISS1R gene. ${ }^{21)}$ Kisspeptin is the most potent stimulator of GnRH secretion. ${ }^{21)}$ A higher level of kisspeptin augments the pulsatile release of GnRH. ${ }^{21)}$ Elevated kisspeptin levels are associated with CPP. ${ }^{22)} \mathrm{A}$ study showed that KISS1 mutations lead to CPP, which then leads to elevated kisspeptin levels. ${ }^{23)}$ In that study, a higher kisspeptin concentration resulted from resistance to degradation. Higher kisspeptin levels were observed in girls with CPP than in agematched prepubertal controls. ${ }^{24)}$ In addition, kisspeptin levels were significantly reduced after 6 months of treatment compared to those at the start of treatment in girls with CPP.25) $\mathrm{A}$ Korean study showed that genetic variations in the KISS1 gene are related to the development of CPP. ${ }^{26)}$ However, kisspeptin mutations appear to account for very few cases of CPP, as largescale studies in children with CPP failed to identify additional individuals harboring abnormalities in these genes. ${ }^{27)}$ Mutations have not been identified in girls with CPP, although a few studies have evaluated genetic alterations in the KISS1 gene. ${ }^{28)}$

\section{Kisspeptin receptor (KISS1R) gene}

The kisspeptin receptor, also known as G-protein-coupled receptor 54 (GPR54), has a structure similar to that of the galanin receptor. ${ }^{29)}$ The activated kisspeptin receptor, which results from the binding of its ligand, kisspeptin, recruits secondary intracellular messengers such as inositol triphosphate and diacyl. glycerol..$^{30)}$ This process leads to the release of intracellular cal- cium and activation of protein kinase $\mathrm{C}^{30)}$ A study suggested that an autosomal-dominant missense mutation in KISS1R (a gainof-function mutation) results in activation of the intracellular signaling pathway and can be related to $\mathrm{CPP}{ }^{31)} \mathrm{A}$ recent Korean study suggested that sequence variants of the KISS1R gene were related to CPP in girls. ${ }^{32)}$ However, few studies have identified mutations in these genes in girls with CPP. Although the KISS1 and KISS1R genes play a pivotal role in pubertal onset mediated by GnRH secretion, they do not seem to account for a significant number of CPP cases in children.

\section{Makorin ring finger protein 3 (MKRN3) gene}

The MKRN3 gene, which is located within the Prader-Willi syndrome (PWS) region on chromosome $15 \mathrm{q} 11.2$, is maternally imprinted (in other words, paternally expressed) and encodes MKRN3, a zinc finger protein. MKRN3 is characterized by zinc finger RING, which is found in most $\mathrm{E} 3$ ubiquitin ligases. ${ }^{33)}$ E3 ubiquitin ligases serve as a component of the degradation of intracellular proteins called the Ub-proteasome pathway, whereas extracellular proteins and some cell surface proteins are degraded within lysosomes. ${ }^{34)}$ MKRN3 may interact with multiple proteins related to pubertal timing, insulin signaling, RNA metabolism and cell-to-cell adhesion. ${ }^{35}$ In a mouse model, Mkrn3 bound to neuronal pentraxin-1 (Nptx1), which plays a role in neuronal development and is highly expressed during pubertal onset. ${ }^{36} \mathrm{Nptx} 1$ may be degraded via polyubiquitination after interacting with the $\mathrm{E} 3$ ubiquitin ligase domain in Mkrn3. ${ }^{36}$ ) Highly expressed Mkrn3 is observed in the hypothalamus of mice during the neonatal and juvenile period, whereas abruptly decreased expressed Mkrn3 was observed before pubertal development. ${ }^{37)} \mathrm{Mkrn} 3$ plays an inhibitory role in pubertal onset in mice The MKRN3 gene is believed to suppress pubertal onset in humans as well. ${ }^{37)}$ The inhibitory role of the MKRN3 
gene in humans has been supported by a number of studies. A few studies have suggested that decreased serum MKRN3 levels are observed in girls and boys before pubertal onset. ${ }^{38)}$ Serum levels of MKRN3 were lower in girls with CPP versus their agematched controls. ${ }^{39)}$ In addition, multiple variants in MKRN3, including frameshift, nonsense, and missense, which can lead to decreased MKRN3 functioning, have been suggested as linked to CPP across ethnicities and nations. ${ }^{40)} \mathrm{A}$ meta-analysis suggested that mutations in $M K R N 3$ were found much more frequently in familial CPP (approximately 46\%) than in sporadic CPP (approximately 4\%) cases, and they are considered the most common cause of familial CPP. ${ }^{41)}$ In that study, the median age at puberty onset was relatively early at 6.0 years in girls and 8.25 years in boys. ${ }^{41}$ )

\section{Delta-like homolog 1 (DLK1) gene}

The DLK1 gene, located on chromosome 14q32.2, is maternally imprinted but paternally expressed as the MKRN3 gene. ${ }^{42)}$ This region includes imprinted genes (DLK1-DIO3 domain) associated with Kagami-Ogata syndrome, which is related to maternally expressed genes, and Temple syndrome, which is associated with paternally expressed genes. ${ }^{42)}$ The DLK1 gene has 5 exons (transcript length: 4657 bp in humans), and it encodes a transmembrane protein belonging to the epidermal growth factor-like family of proteins, which includes Notch receptors and Delta and Serrate ligands; it is part of the Delta Notch pathway, a signaling pathway conserved across species during evolution. ${ }^{42)}$

The signaling pathway in mammals has 4 Notch receptors (Notch 1-4), 5 canonical ligands (Dll1, Dll3, Dll4, Jagged1, and Jagged2) which include the Delta, Serrate, and Lag2 (DSL) domain, and 2 noncanonical ligands (Dlk1, Dlk2). ${ }^{43}$ Whereas canonical Notch ligands play a role in activating the Notch cascade through cell-to-cell interactions, noncanonical Notch ligands, including Dlk1, inhibit Notch signaling. Notch signaling cascades reportedly promote cell proliferation, apoptosis, and differentiation during embryonic development, and to regulate tissue homeostasis and stem cell maintenance in adults. ${ }^{44)}$ The DLK1 protein plays a role in the differentiation of neuroendocrine cells as well as osteogenesis, adipogenesis, hematopoiesis, and hepatocyte production. ${ }^{45)}$ In mice, Dlk1 is reportedly encoded in neuroendocrine tissues including the pituitary gland during fetal development ${ }^{46)}$; it is also observed postnatally in the hypothalamus, including the medio-basal hypothalamus, a control center for $\mathrm{GnRH}$ secretion. ${ }^{47)}$

The formation of kisspeptin neurons in the hypothalamus requires sufficient Notch signaling in early neuronal development. ${ }^{48)}$ Notch signaling is also required for the development of kisspeptin neurons in adulthood. ${ }^{48)}$ Although the mechanism between DLK1 and pubertal timing is fully established, it is postulated that an inhibitory role of DLK1 could regulate kisspeptin neuron formation and maturation and/or kisspeptin secretion. ${ }^{49)}$ Indeed, a very recent study demonstrated a paternally expressed imprinted pattern of genomic defects in
DLK1, including a 14-kb deletion and 269-bp duplication in a family with 5 female members with CPP. ${ }^{50)}$ A subsequent study reported 3 frameshift mutations in DLK1 in five women from 3 families with CPP. ${ }^{51)}$ Another study from Korea suggested 5 polymorphisms in DLK1 in 100 girls with ICPP. ${ }^{52)}$ In that study, only a polymorphism reportedly resulted in splicing defects in an in silico study, suggesting that DLK1 mutations may be a relatively rare cause of ICPP.52)

\section{Gamma-aminobutyric acid receptor a1 subunit (GABRA1) gene}

GABRA1, located on chromosome $5 \mathrm{q} 34$, encodes the gammaaminobutyric acid (GABA)-A receptor $\alpha 1$ subunit, a GABA-A receptor that is a ligand-gated ion channel consisting of at least 18 different subunits $(\alpha 1-\alpha 6, \beta 1-\beta 4, \gamma 1-\gamma 4, \delta, \pi$, and $\left.\rho 1-\rho 2) .{ }^{53}\right)$ GABA, a ligand for the GABA-A receptor, reportedly plays a role in inhibitory neurotransmitters in the intrinsic mechanism of the onset of puberty in primates. ${ }^{54)}$ Of several GABA-A receptors, the $\alpha 1$ subunit is suggested to be related to the inhibitory activity of GABA on GnRH release. A study demonstrated that reducing tonic GABA inhibition via competitive antagonism of GABA-A receptors (bicuculine) is related to advanced pubertal onset in monkeys. ${ }^{55)}$ The GABAergic inhibition of GnRH neurons via the GABA-A receptor $\alpha 1$ subunit seems to be critical for repressing pubertal onset. ${ }^{56)}$ Loss-of-function mutations or polymorphisms in GABRA1 can be established to explain premature $\mathrm{GnRH}$ release. However, a study of the GABRA1 gene in 31 girls with ICPP found no functional GABRA1 mutations. ${ }^{57)}$ That study identified 7 GABRA1 polymorphisms in 2 exons (156T $>\mathrm{C}$ and $1323 \mathrm{G}>\mathrm{A}$ ) and 5 introns (IVS2-712(GT)n, IVS3 + 12A $>$ T, IVS8 +45 T $>$ G, IVS9 $+76 \mathrm{~A}>\mathrm{G}$, and IVS10 + 15G $>\mathrm{A}) .57$ ) A subsequent study suggested that GABA-A receptor knockout mice exhibited normal pubertal onset and reduced amplitudes and frequencies of GABA-A postsynaptic currents. ${ }^{58)}$

\section{Lin-28 homolog B (LIN28B) gene}

The $L I N 28 B$ gene is a human homolog of the lineage-28 (lin28) gene of Caenorhabditis elegans that is essential for the timing of developmental events. ${ }^{59)}$ LIN28B is a highly conserved RNAbinding protein that blocks microRNAs of the LET7 microRNA family. ${ }^{59)}$ LIN28B and the LET7 microRNA family reportedly play a role in embryonic stem cell self-renewal, cell developmental and differential processes, metabolism, and oncogenesis. It may also be involved in pubertal development. A few studies have suggested that $L I N 28 B$ is involved in CPP. ${ }^{60)} L I N 28 B$ was suggested to be related to earlier breast development, earlier menarche, and more advanced pubic hair development in a meta-analysis of genome-wide association studies. ${ }^{61)}$ Some studies reported that the rs314276 genotype in $L I N 28 B$ is associated with earlier puberty or CPP. ${ }^{62}$ Polymorphism in $L I N 28 B$, including rs7759938 and rs314280, is related to the risk of ICPP ${ }^{63)}$ However, another study evaluated the association between variants in LIN28B and ICPP in 178 Brazilian children with CPP but did not show the causative relationship. ${ }^{64)}$ More- 
over, genetic variations in LIN28B, such as rs314276, are reportedly associated with increased weight and BMI. ${ }^{62)}$ Obesity is strongly related to early pubertal development. ${ }^{10)}$ Thus, the role of the LIN28B gene in ICPP remains unclear.

\section{Neuropeptide $Y(N P Y R)$ gene}

Neuropeptide Y (NPY), which is highly conserved across many species, is abundant in the peripheral and central nervous systems. ${ }^{65)}$ This 36 -amino-acid peptide is considered a major component in the inhibition of pulsatile $\mathrm{GnRH}$ secretion during the prepubertal period in nonhuman primates. ${ }^{65)}$ The central administration of NPY inhibited pulsatile GnRH release in adult female monkeys. ${ }^{66)}$ The NPY gene and its protein expression in monkeys were negatively related to $\mathrm{GnRH}$ pulse generator activity. ${ }^{67)}$ NPY is considered a fundamental component of pubertal onset in primates. NPY interacts with a family of G-protein coupled receptors (NYP receptors) encoding the NPYR gene located on chromosome 4q, which includes the Y1, Y2, Y4, Y5, and Y6 subtypes. ${ }^{68)}$ Of them, the Y1R subtype reportedly regulates hormone secretion and is implicated in the effects of NYP on GnRH release. ${ }^{69)}$ A causal relationship was observed between mutations or polymorphisms in the NPYR gene and ICPP. ${ }^{70)} \mathrm{A}$ Brazilian study attempted to evaluate NPYR1 mutations or polymorphisms in 33 girls with familial ICPP. ${ }^{71)}$ Although a heterozygous synonymous polymorphism (K374T) was found, it did not result in amino acid substitution and was detected in the control population at a high prevalence (28\%). ${ }^{71)}$ In addition, they did not detect altered polymorphisms via in vitro assays. ${ }^{71)}$

\section{Tachykinin 3 (TAC3) and tachykinin receptor 3 (TACR3) genes}

TAC3 and TACR3 genes encode NKB and the G proteincoupled receptor neurokinin (NK3R). ${ }^{72)} \mathrm{NKB}$ is a mammalian tachykinin family of peptides such as substance $\mathrm{P}(\mathrm{SP})$, neurokinin $\mathrm{A}(\mathrm{NKA}), \mathrm{NKB}$, neuropeptide $\mathrm{K}$, and neuropeptide $\mathrm{Y}$ (NPY). ${ }^{72)}$ These tachykinins reportedly mediate nonadrenergic and noncholinergic excitatory neurotransmissions. ${ }^{72)}$ There are 3 main classes of neurokinin receptors, including NK1R (SP preferring receptor), NK2R (NKA preferring receptor), and NK3R (NKB preferring receptor). NKB and NK3R are co-expressed with KNDy neurons. ${ }^{73)}$ The NKB system has been implicated as a regulator of human reproduction. In a primate study, an NKB or NKB analog (senktide) led to robust GnRH secretion. ${ }^{74)}$ Loss-of-function mutations in the TAC3 or TACR3 genes were identified in subjects with familial hypogonadotropic hypogonadism, suggesting that the NKB and NK3R pathways are indispensable components of pubertal onset. ${ }^{75)}$ In addition, a mutation in the TACR3 gene was identified in a patient with ICPP. ${ }^{76)}$ Other studies revealed variants in TAC3 or TACR3 genes in patients with ICPP. ${ }^{77)}$ However, the association between variants or mutations in the TAC3 or TACR 3 genes and ICPP has yet to be confirmed, and functional assays for this mutation are needed.

\section{Nongenetic factors associated with ICPP}

\section{Environmental and socioeconomic factors}

Variations in pubertal onset are related to environmental factors, such as nutrition, intrauterine conditions, and exposure to endocrine-disrupting chemicals (EDCs). ${ }^{18)}$ Interactions with the environment and hypothalamic signals are thought contribute to the downward secular trend of pubertal timing in developed and developing countries. Several studies have shown the trends of earlier timing of pubertal development, including the Republic of Korea. ${ }^{78)}$ Obesity due to improved nutrition is thought to be strongly linked to the downward secular trend in the timing of puberty and these differences. On dual-energy $\mathrm{x}$-ray absorptiometry and according to estimated BMI, an earlier age at menarche was related to an increased body fat mass due to an improved diet. ${ }^{79)}$ Intrauterine growth restriction or small for gestational age (SGA) status is reportedly related to earlier age at pubertal development in the general population ${ }^{80)}$ as well as CPP in patients with Silver-Russel syndrome. ${ }^{81)}$ In addition, EDCs are known to be responsible for earlier pubertal onset. However, the mechanism between idiopathic CPP and nongenetic environmental factors remains unclear. These relationships are suspected to be mediated by genetic effects. ${ }^{82}$

\section{Epigenetic factors}

It seems reasonable that puberty onset is regulated as an alternative pathway. It has been suggested that the epigenetic modification of gene expression, specifically heritable changes in gene expression that occur without changing a gene's primary nucleotide sequence, may be an alternative pathway. ${ }^{83)}$ Modes of epigenetic regulation involve DNA methylation, histone posttranslational modifications, and noncoding ribonucleic acids (miRNAs) ${ }^{84)}$ Gene-specific gatekeeper functions and gene expression plasticity are believed regulated by epigenetic mechanisms. ${ }^{85)}$ Epigenetic information is reportedly involved in sexual differentiation of the brain. ${ }^{86}$ ) The epigenetic mechanism of transcriptional repression in the hypothalamus reportedly played a role in the timing of pubertal onset in a rat model. ${ }^{87)}$

The polycomb group (PcG) complex is considered a major contributor to this repressive mechanism. Expression of the PcG complex in the hypothalamus is decreased at puberty, which is associated with the acquisition of epigenetic silencing marks such as DNA methylation and histone modification. ${ }^{88)}$ In brief, PcG of transcriptional repressors prevent the premature initiation of puberty by inhibiting Kiss 1 transcription in KNDy neurons. ${ }^{89)}$ Although Kiss 1 expression has been suggested to be inhibited in the prepubertal period, the promoters of PcG complexes become methylated at the timing of pubertal onset, allowing other epigenetic modifications such as epigenetic activators to turn on the switch of puberty. ${ }^{88)}$ Changes in chromatin status due to the separation of PcG components from the promoter reportedly result in increased epigenetic marks, allowing gene activation. These changes can lead to elevated mRNA expression in Kiss $1^{90)}$ cell. The Kiss1 promoter, in which repressing and 
activating marks coexist, is also subjected to increasing epigenetic-activating marks. ${ }^{91)}$ Elevated levels of an activating transcriptional complex can be observed along with the loss of PcG inhibition. ${ }^{91)}$

The trithorax group (TrxG) complex is suggested to play a role as a promoter and enhancer in the Kiss1 gene. ${ }^{91)}$ The TrxG complex may assist in driving out PcG by demethylating repressive histones, increasing an active enhancer. By implementing the $\operatorname{Trx} G$, an epigenetic modification is suggested to change the Kiss 1 gene from a repressed to active state at the timing of pubertal onset. ${ }^{91)}$ However, the epigenetic mechanism of ICPP in human remains unclear.

A possible mechanism between epigenetics and pubertal onset may be found in the MKRN3 gene in humans. The gene is expressed by only one of the inherited alleles and may be fragile to genetic mutations and/or epigenetic modifications in the coding and regulating regions. For PWS, the MKRN3 gene is activated from a paternally imprinted region. ${ }^{92)}$ Mutations in the promoter region of $M K R N 3$ are suggested to alter Mkrn3 expression by disrupting the binding of specific transcription factors. ${ }^{93}$ ) Altered methylation at the MKRN3 gene is postulated to be involved in pubertal onset. However, a previous study suggested a possible mechanism between changes in methylation and pubertal onset. ${ }^{94)}$ Zinc finger protein 57 (ZFP57), a C2H2 zinc finger protein that contains a repressive Krüppel-associated box (KRAB) domain, ${ }^{95}$ ) is considered to regulate genomic imprinting, including $M K R N 3 .{ }^{96)}$ Hypomethylation of the promoter region of ZFP57 was identified in the blood cells of pubertal girls, while elevated ZFP57 expression was observed in the hypothalamus of female monkeys at pubertal onset. In addition, KRAB-associating protein (KAP1) is a ZFP57-cofactor and considered to play a role in DNA methylation. Knockout of the ZFP57 cofactor is related to elevated hippocampal Mkrn3 expression. ${ }^{97)}$ Regulation of the ZFP57 and KAP1 genes may alter chromatin structure and regulate transcription, including imprinted regions. ${ }^{98)}$ It is possible that elevated ZFP57 levels mediate the alteration of $M K R N 3$ chromatin to facilitate its repression and allow pubertal onset, ${ }^{99)}$ although this has yet to be confirmed.

\section{Conclusion}

Pubertal onset seems to be minutely controlled by interactions between genetic and nongenetic factors. ICPP is a result of the premature activation of these interactions. Recently identified genetic factors aid our understanding of the early development of puberty. The KISS1, KISS1R, MKRN3, and DLK1 genes contribute to the established genetic factors related to ICPP, whereas the GABRA1, LIN28B, NPYR, TAC3, and TACR3 genes are considered possibly related to CPP. ${ }^{18,23,31,39,51)}$ Environmental and socioeconomic factors, such as nutrition, SGA, and EDCs, may also be involved in ICPP. Epigenetic control may mediate the relationship between genetic factors and environmental and socioeconomic factors. A variety of studies are still needed to validate the mysterious pathophysiology of puberty regulation as new factors continue to emerge. Comprehensive and step-bystep research of genetic and nongenetic factors can increase our understanding of the exact mechanism of ICPP.

\section{Footnotes}

Conflicts of interest: No potential conflict of interest relevant to this article was reported.

Funding: This study received no specific grant from any funding agency in the public, commercial, or not-for-profit sectors.

ORCID:

Young Suk Shim (D) https://orcid.org/0000-0002-0850-5279

Jin Soon Hwang (D) https://orcid.org/0000-0002-2666-3801

\section{References}

1. Remschmidt H. Mental health and psychological illness in adolescence. Dtsch Arztebl Int 2013;110:423-4.

2. Palmert MR, Boepple PA. Variation in the timing of puberty: clinical spectrum and genetic investigation. J Clin Endocrinol Metab 2001;86: 2364-8.

3. Fergani C, Navarro VM. Expanding the role of tachykinins in the neuroendocrine control of reproduction. Reproduction 2016;153:R114.

4. Wheeler MD. Physical changes of puberty. Endocrinol Metab Clin North Am 1991;20:1-14.

5. Latronico AC, Brito VN, Carel JC. Causes, diagnosis, and treatment of central precocious puberty. Lancet Diabetes Endocrinol 2016;4:265-74.

6. Cho GJ, Park HT, Shin JH, Hur JY, Kim YT, Kim SH, et al. Age at menarche in a Korean population: secular trends and influencing factors. Eur J Pediatr 2010;169:89-94.

7. Seo MY, Kim SH, Juul A, Park MJ. Trend of menarcheal age among Korean girls. J Korean Med Sci 2020;35:e406.

8. Roelants M, Hauspie R, Hoppenbrouwers K. References for growth and pubertal development from birth to 21 years in Flanders, Belgium. Ann Hum Biol 2009;36:680-94.

9. Marshall WA, Tanner JM. Variations in pattern of pubertal changes in girls. Arch Dis Child 1969;44:291-303.

10. Semiz S, Kurt F, Kurt DT, Zencir M, Sevinç O. Pubertal development of Turkish children. J Pediatr Endocrinol Metab 2008;21:951-61.

11. Prentice P, Viner RM. Pubertal timing and adult obesity and cardiometabolic risk in women and men: a systematic review and meta-analysis. Int J Obes (Lond) 2013;37:1036-43.

12. Ritte R, Lukanova A, Tjønneland A, Olsen A, Overvad K, Mesrine S, et al. Height, age at menarche and risk of hormone receptor-positive and -negative breast cancer: a cohort study. Int J Cancer 2013;132:2619-29.

13. Cance JD, Ennett ST, Morgan-Lopez AA, Foshee VA, Talley AE. Perceived pubertal timing and recent substance use among adolescents: a longitudinal perspective. Addiction 2013;108:1845-54.

14. Partsch CJ, Sippell WG. Pathogenesis and epidemiology of precocious puberty. Effects of exogenous oestrogens. Hum Reprod Update 2001;7: 292-302.

15. Carel JC, Léger J. Clinical practice. Precocious puberty. N Engl J Med 2008;358:2366-77.

16. Yoon JS, So CH, Lee HS, Lim JS, Hwang JS. The prevalence of brain abnormalities in boys with central precocious puberty may be overestimated. PLoS One 2018;13:e0195209. 
17. Bajpai A, Menon PS. Contemporary issues in precocious puberty. Indian J Endocrinol Metab 2011;15 Suppl 3:S172-9.

18. Leka-Emiri S, Chrousos GP, Kanaka-Gantenbein C. The mystery of puberty initiation: genetics and epigenetics of idiopathic central precocious puberty (ICPP). J Endocrinol Invest 2017;40:789-802.

19. Sørensen S, Brix N, Ernst A, Lauridsen LLB, Ramlau-Hansen $\mathrm{CH}$. Maternal age at menarche and pubertal development in sons and daughters: a Nationwide Cohort Study. Hum Reprod 2018;33:2043-50.

20. Treloar SA, Martin NG. Age at menarche as a fitness trait: nonadditive genetic variance detected in a large twin sample. Am J Hum Genet 1990; 47:137-48.

21. Bianco SD. A potential mechanism for the sexual dimorphism in the onset of puberty and incidence of idiopathic central precocious puberty in children: sex-specific kisspeptin as an integrator of puberty signals. Front Endocrinol (Lausanne) 2012;3:149.

22. Clarke H, Dhillo WS, Jayasena CN. Comprehensive review on kisspeptin and its role in reproductive disorders. Endocrinol Metab (Seoul) 2015; 30:124-41.

23. Silveira LG, Noel SD, Silveira-Neto AP, Abreu AP, Brito VN, Santos MG, et al. Mutations of the KISS1 gene in disorders of puberty. J Clin Endocrinol Metab 2010;95:2276-80.

24. Rhie YJ, Lee KH, Eun SH, Choi BM, Chae HW, Kwon AR, et al. Serum kisspeptin levels in Korean girls with central precocious puberty. J Korean Med Sci 2011;26:927-31.

25. Demirbilek H, Gonc EN, Ozon A, Alikasifoglu A, Kandemir N. Evaluation of serum kisspeptin levels in girls in the diagnosis of central precocious puberty and in the assessment of pubertal suppression. J Pediatr Endocrinol Metab 2012;25:313-6.

26. Rhie YJ, Lee KH, Ko JM, Lee WJ, Kim JH, Kim HS. KISS1 gene polymorphisms in Korean girls with central precocious puberty. J Korean Med Sci 2014;29:1120-5.

27. Shin YL. An update on the genetic causes of central precocious puberty. Ann Pediatr Endocrinol Metab 2016;21:66-9.

28. Leka-Emiri S, Louizou E, Kambouris M, Chrousos G, De Roux N, Kanaka-Gantenbein C. Absence of GPR54 and TACR3 mutations in sporadic cases of idiopathic central precocious puberty. Horm Res Paediatr 2014;81:177-81.

29. Kotani M, Detheux M, Vandenbogaerde A, Communi D, Vanderwinden JM, Le Poul E, et al. The metastasis suppressor gene KiSS-1 encodes kisspeptins, the natural ligands of the orphan $\mathrm{G}$ protein-coupled receptor GPR54. J Biol Chem 2001;276:34631-6.

30. Liu X, Lee K, Herbison AE. Kisspeptin excites gonadotropin-releasing hormone neurons through a phospholipase $\mathrm{C} /$ calcium-dependent pathway regulating multiple ion channels. Endocrinology 2008;149:4605-14.

31. Teles MG, Bianco SD, Brito VN, Trarbach EB, Kuohung W, Xu S, et al. A GPR54-activating mutation in a patient with central precocious puberty. NEngl J Med 2008;358:709-15.

32. Oh YJ, Rhie YJ, Nam HK, Kim HR, Lee KH. Genetic variations of the KISS1R gene in Korean girls with central precocious puberty. J Korean Med Sci 2017;32:108-14.

33. Jong MT, Carey AH, Caldwell KA, Lau MH, Handel MA, Driscoll DJ, et al. Imprinting of a RING zinc-finger encoding gene in the mouse chromosome region homologous to the Prader-Willi syndrome genetic region. Hum Mol Genet 1999;8:795-803.

34. Rock KL, Gramm C, Rothstein L, Clark K, Stein R, Dick L, et al. Inhibitors of the proteasome block the degradation of most cell proteins and the generation of peptides presented on MHC class I molecules. Cell 1994;78:761-71.

35. Yellapragada V, Liu X, Lund C, Känsäkoski J, Pulli K, Vuoristo S, et al. MKRN3 interacts with several proteins implicated in puberty timing but does not influence GNRH1 expression. Front Endocrinol (Lausanne) 2019;10:48.

36. Liu H, Kong X, Chen F. Mkrn3 functions as a novel ubiquitin E3 ligase to inhibit Nptx1 during puberty initiation. Oncotarget 2017;8:85102-9.

37. Abreu AP, Dauber A, Macedo DB, Noel SD, Brito VN, Gill JC, et al. Central precocious puberty caused by mutations in the imprinted gene MKRN3. NEngl J Med 2013;368:2467-75.
38. Busch AS, Hagen CP, Almstrup K, Juul A. Circulating MKRN3 levels decline during puberty in healthy boys. J Clin Endocrinol Metab 2016; 101:2588-93.

39. Jeong HR, Lee HJ, Shim YS, Kang MJ, Yang S, Hwang IT. Serum Makorin ring finger protein 3 values for predicting Central precocious puberty in girls. Gynecol Endocrinol 2019;35:732-6.

40. Aycan Z, Savaş-Erdeve Ş, Çetinkaya S, Kurnaz E, Keskin M, Muratoğlu Şahin N, et al. Investigation of MKRN3 mutation in patients with familial central precocious puberty. J Clin Res Pediatr Endocrinol 2018;10:223-9.

41. Valadares LP, Meireles CG, De Toledo IP, Santarem de Oliveira R, Gonçalves de Castro LC, Abreu AP, et al. MKRN3 mutations in central precocious puberty: a systematic review and meta-analysis. J Endocr Soc 2019;3:979-95.

42. Andersson ER, Sandberg R, Lendahl U. Notch signaling: simplicity in design, versatility in function. Development 2011;138:3593-612.

43. Arruga F, Vaisitti T, Deaglio S. The NOTCH pathway and its mutations in mature B cell malignancies. Front Oncol 2018;8:550.

44. D'Souza B, Meloty-Kapella L, Weinmaster G. Canonical and noncanonical Notch ligands. Curr Top Dev Biol 2010;92:73-129.

45. Sánchez-Solana B, Nueda ML, Ruvira MD, Ruiz-Hidalgo MJ, Monsalve EM, Rivero S, et al. The EGF-like proteins DLK1 and DLK2 function as inhibitory non-canonical ligands of NOTCH1 receptor that modulate each other's activities. Biochim Biophys Acta 2011;1813:1153-64.

46. Jensen CH, Meyer M, Schroder HD, Kliem A, Zimmer J, Teisner B. Neurons in the monoaminergic nuclei of the rat and human central nervous system express FA1/dlk. Neuroreport 2001;12:3959-63.

47. Villanueva C, Jacquier S, de Roux N. DLK1 is a somato-dendritic protein expressed in hypothalamic arginine-vasopressin and oxytocin neurons. PLoS One 2012;7:e36134.

48. Biehl MJ, Raetzman LT. Rbpj-א mediated Notch signaling plays a critical role in development of hypothalamic Kisspeptin neurons. Dev Biol 2015;406:235-46.

49. Macedo DB, Kaiser UB. DLK1, Notch signaling and the timing of puberty. Semin Reprod Med 2019;37:174-81.

50. Dauber A, Cunha-Silva M, Macedo DB, Brito VN, Abreu AP, Roberts SA, et al. Paternally inherited DLK1 deletion associated with familial central precocious puberty. J Clin Endocrinol Metab 2017;102:1557-67.

51. Gomes LG, Cunha-Silva M, Crespo RP, Ramos CO, Montenegro LR, Canton A, et al. DLK1 is a novel link between reproduction and metabolism. J Clin Endocrinol Metab 2019;104:2112-20.

52. Lee HS, Kim KH, Hwang JS. Association study of DLK1 in girls with idiopathic central precocious puberty. J Pediatr Endocrinol Metab 2020; 8:1045-9.

53. Terasawa E, Fernandez DL. Neurobiological mechanisms of the onset of puberty in primates. Endocr Rev 2001;22:111-51.

54. Plant TM, Barker-Gibb ML. Neurobiological mechanisms of puberty in higher primates. Hum Reprod Update 2004;10:67-77.

55. Keen KL, Burich AJ, Mitsushima D, Kasuya E, Terasawa E. Effects of pulsatile infusion of the GABA(A) receptor blocker bicuculline on the onset of puberty in female rhesus monkeys. Endocrinology 1999;140: 5257-66.

56. Ojeda SR, Prevot V, Heger S, Lomniczi A, Dziedzic B, Mungenast A. Gliato-neuron signaling and the neuroendocrine control of female puberty. Ann Med 2003;35:244-55.

57. Brito VN, Mendonca BB, Guilhoto LM, Freitas KC, Arnhold IJ, Latronico AC. Allelic variants of the gamma-aminobutyric acid-A receptor alpha1-subunit gene (GABRA1) are not associated with idiopathic gonadotropin-dependent precocious puberty in girls with and without electroencephalographic abnormalities. J Clin Endocrinol Metab 2006; 91:2432-6.

58. Lee K, Porteous R, Campbell RE, Lüscher B, Herbison AE. Knockdown of GABA(A) receptor signaling in GnRH neurons has minimal effects upon fertility. Endocrinology 2010;151:4428-36.

59. Viswanathan SR, Daley GQ, Gregory RI. Selective blockade of microRNA processing by Lin28. Science 2008;320:97-100.

60. Perry JR, Stolk L, Franceschini N, Lunetta KL, Zhai G, McArdle PF, et al. Meta-analysis of genome-wide association data identifies two loci 
influencing age at menarche. Nat Genet 2009;41:648-50.

61. Ong KK, Elks CE, Li S, Zhao JH, Luan J, Andersen LB, et al. Genetic variation in LIN28B is associated with the timing of puberty. Nat Genet 2009;41:729-33.

62. Ong KK, Elks CE, Wills AK, Wong A, Wareham NJ, Loos RJ, et al. Associations between the pubertal timing-related variant in LIN28B and BMI vary across the life course. J Clin Endocrinol Metab 2011;96:E125-9.

63. Hu Z, Chen R, Cai C. Association of genetic polymorphisms around the LIN28B gene and idiopathic central precocious puberty risks among Chinese girls. Pediatr Res 2016;80:521-5.

64. Silveira-Neto AP, Leal LF, Emerman AB, Henderson KD, Piskounova E, Henderson BE, et al. Absence of functional LIN28B mutations in a large cohort of patients with idiopathic central precocious puberty. Horm Res Paediatr 2012;78:144-50.

65. Terasawa E. Mechanism of pulsatile GnRH release in primates: unresolved questions. Mol Cell Endocrinol 2019;498:110578.

66. Pau KY, Berria M, Hess DL, Spies HG. Hypothalamic site-dependent effects of neuropeptide $\mathrm{Y}$ on gonadotropin-releasing hormone secretion in rhesus macaques. J Neuroendocrinol 1995;7:63-7.

67. El Majdoubi M, Sahu A, Ramaswamy S, Plant TM. Neuropeptide Y: a hypothalamic brake restraining the onset of puberty in primates. Proc Natl Acad Sci US A 2000;97:6179-84.

68. Michel MC, Beck-Sickinger A, Cox H, Doods HN, Herzog H, Larhammar D, et al. XVI. International Union of Pharmacology recommendations for the nomenclature of neuropeptide Y, peptide YY, and pancreatic polypeptide receptors. Pharmacol Rev 1998;50:143-50.

69. Balasubramaniam A. Clinical potentials of neuropeptide Y family of hormones. Am J Surg 2002;183:430-4.

70. Kim GL, Dhillon SS, Belsham DD. Kisspeptin directly regulates neuropeptide $\mathrm{Y}$ synthesis and secretion via the ERK1/2 and p38 mitogenactivated protein kinase signaling pathways in NPY-secreting hypothalamic neurons. Endocrinology 2010;151:5038-47.

71. Freitas KC, Ryan G, Brito VN, Tao YX, Costa EM, Mendonca BB, et al. Molecular analysis of the neuropeptide Y1 receptor gene in human idiopathic gonadotropin-dependent precocious puberty and isolated hypogonadotropic hypogonadism. Fertil Steril 2007;87:627-34.

72. Page NM, Woods RJ, Lowry PJ. A regulatory role for neurokinin B in placental physiology and pre-eclampsia. Regul Pept 2001;98:97-104.

73. Hrabovszky E, Ciofi P, Vida B, Horvath MC, Keller E, Caraty A, et al. The kisspeptin system of the human hypothalamus: sexual dimorphism and relationship with gonadotropin-releasing hormone and neurokinin B neurons. Eur J Neurosci 2010;31:1984-98.

74. Ramaswamy S, Seminara SB, Ali B, Ciofi P, Amin NA, Plant TM. Neurokinin B stimulates GnRH release in the male monkey (Macaca mulatta) and is colocalized with kisspeptin in the arcuate nucleus. Endocrinology 2010;151:4494-503.

75. Topaloglu AK, Reimann F, Guclu M, Yalin AS, Kotan LD, Porter KM, et al. TAC3 and TACR3 mutations in familial hypogonadotropic hypogonadism reveal a key role for Neurokinin B in the central control of reproduction. Nat Genet 2009;41:354-8.

76. Teles MG, Silveira LF, Tusset C, Latronico AC. New genetic factors implicated in human GnRH-dependent precocious puberty: the role of kisspeptin system. Mol Cell Endocrinol 2011;346:84-90.

77. Xin X, Zhang J, Chang Y, Wu Y. Association study of TAC3 and TACR3 gene polymorphisms with idiopathic precocious puberty in Chinese girls. J Pediatr Endocrinol Metab 2015;28:65-71.

78. Euling SY, Herman-Giddens ME, Lee PA, Selevan SG, Juul A, Sørensen TI, et al. Examination of US puberty-timing data from 1940 to 1994 for secular trends: panel findings. Pediatrics 2008;121 Suppl 3:S172-91.

79. Merzenich $\mathrm{H}$, Boeing $\mathrm{H}$, Wahrendorf J. Dietary fat and sports activity as determinants for age at menarche. Am J Epidemiol 1993;138:217-24.

80. Deng X, Li W, Luo Y, Liu S, Wen Y, Liu Q. Association between small fetuses and puberty timing: a systematic review and meta-analysis. Int J Environ Res Public Health 2017;14:1377.

81. Silver HK. Asymmetry, short stature, and variations in sexual development. A syndrome of congenital malformations. Am J Dis Child 1964; 107:495-515.
82. Kaprio J, Rimpelä A, Winter T, Viken RJ, Rimpelä M, Rose RJ. Common genetic influences on BMI and age at menarche. Hum Biol 1995; 67:739-53.

83. Bjornsson HT, Fallin MD, Feinberg AP. An integrated epigenetic and genetic approach to common human disease. Trends Genet 2004;20: 350-8.

84. Herman JG, Baylin SB. Gene silencing in cancer in association with promoter hypermethylation. N Engl J Med 2003;349:2042-54.

85. Garcia-Bassets I, Kwon YS, Telese F, Prefontaine GG, Hutt KR, Cheng CS, et al. Histone methylation-dependent mechanisms impose ligand dependency for gene activation by nuclear receptors. Cell 2007;128: 505-18.

86. McCarthy MM, Auger AP, Bale TL, De Vries GJ, Dunn GA, Forger NG, et al. The epigenetics of sex differences in the brain. J Neurosci 2009;29:12815-23.

87. Kelly KF, Daniel JM. POZ for effect--POZ-ZF transcription factors in cancer and development. Trends Cell Biol 2006;16:578-87.

88. Lomniczi A, Wright H, Ojeda SR. Epigenetic regulation of female puberty. Front Neuroendocrinol 2015;36:90-107.

89. Lomniczi A, Loche A, Castellano JM, Ronnekleiv OK, Bosch M, Kaidar G, et al. Epigenetic control of female puberty. Nat Neurosci 2013;16: 281-9.

90. Toro CA, Aylwin CF, Lomniczi A. Hypothalamic epigenetics driving female puberty. J Neuroendocrinol 2018;30:e12589.

91. Toro CA, Wright H, Aylwin CF, Ojeda SR, Lomniczi A. Trithorax dependent changes in chromatin landscape at enhancer and promoter regions drive female puberty. Nat Commun 2018;9:57.

92. Costa RA, Ferreira IR, Cintra HA, Gomes LHF, Guida LDC. Genotypephenotype relationships and endocrine findings in Prader-Willi Syndrome. Front Endocrinol (Lausanne) 2019;10:864.

93. Fanis P, Skordis N, Toumba M, Papaioannou N, Makris A, Kyriakou A, et al. Central precocious puberty caused by novel mutations in the promoter and 5'-UTR region of the imprinted MKRN3 gene. Front Endocrinol (Lausanne) 2019;10:677.

94. Bessa DS, Maschietto M, Aylwin CF, Canton APM, Brito VN, Macedo $\mathrm{DB}$, et al. Methylome profiling of healthy and central precocious puberty girls. Clin Epigenetics 2018;10:146.

95. Urrutia R. KRAB-containing zinc-finger repressor proteins. Genome Biol 2003;4:231.

96. Li X, Ito M, Zhou F, Youngson N, Zuo X, Leder P, et al. A maternalzygotic effect gene, Zfp57, maintains both maternal and paternal imprints. Dev Cell 2008;15:547-57.

97. Jakobsson J, Cordero MI, Bisaz R, Groner AC, Busskamp V, Bensadoun JC, et al. KAP1-mediated epigenetic repression in the forebrain modulates behavioral vulnerability to stress. Neuron 2008;60:818-31.

98. Quenneville S, Verde G, Corsinotti A, Kapopoulou A, Jakobsson J, Offner S, et al. In embryonic stem cells, ZFP57/KAP1 recognize a methylated hexanucleotide to affect chromatin and DNA methylation of imprinting control regions. Mol Cell 2011;44:361-72.

99. Shalev D, Melamed P. The role of the hypothalamus and pituitary epigenomes in central activation of the reproductive axis at puberty. Mol Cell Endocrinol 2020;518:111031.

100. Li C, Han T, Li Q, Zhang M, Guo R, Yang Y, et al. MKRN3-mediated ubiquitination of Poly(A)-binding proteins modulates the stability and translation of GNRH1 mRNA in mammalian puberty. Nucleic Acids Res 2021;49:3796-813.

101. Seraphim CE, Canton APM, Montenegro L, Piovesan MR, Macedo DB, Cunha M, et al. Genotype-phenotype correlations in central precocious puberty caused by MKRN3 mutations. J Clin Endocrinol Metab 2021; 106:1041-50.

102. Canton APM, Krepischi ACV, Montenegro LR, Costa S, Rosenberg C, Steunou V, et al. Insights from the genetic characterization of central precocious puberty associated with multiple anomalies. Hum Reprod 2021;36:506-18.

103. Varimo T, Iivonen AP, Känsäkoski J, Wehkalampi K, Hero M, Vaaralahti $\mathrm{K}$, et al. Familial central precocious puberty: two novel MKRN3 mutations. Pediatr Res 2021;90:431-5. 
104. Montenegro L, Labarta JI, Piovesan M, Canton APM, Corripio R, Soriano-Guillén L, et al. Novel genetic and biochemical findings of DLK1 in children with central precocious puberty: a Brazilian-Spanish Study. J Clin Endocrinol Metab 2020;105:dgaa461.

105. Abreu AP, Toro CA, Song YB, Navarro VM, Bosch MA, Eren A, et al. MKRN3 inhibits the reproductive axis through actions in kisspeptinexpressing neurons. J Clin Invest 2020;130:4486-500.

106. Pagani S, Calcaterra V, Acquafredda G, Montalbano C, Bozzola E, Ferrara P, et al. MKRN3 and KISS1R mutations in precocious and early puberty. Ital J Pediatr 2020;46:39.

107. Li D, Wu Y, Cheng J, Liu L, Li X, Chen D, et al. Association of polymorphisms in the kisspeptin/GPR54 pathway genes with risk of early puberty in Chinese girls. J Clin Endocrinol Metab 2020;105:dgz229.

108. Chen T, Chen L, Wu H, Xie R, Wang F, Chen X, et al. Low frequency of MKRN3 and DLK1 variants in Chinese children with central precocious puberty. Int JEndocrinol 2019;2019:9879367.

109. Su PY, Xu G, Han AZ, Xu N, Zhang GB, Tao FB. The role of hypothalamus polycomb gene methylation in bisphenol A exposure during pregnancy and premature puberty in female offspring. Zhonghua $\mathrm{Yu}$ Fang Yi Xue Za Zhi 2019;53:303-8.

110. Suzuki E, Shima H, Kagami M, Soneda S, Tanaka T, Yatsuga S, et al. (Epi)genetic defects of MKRN3 are rare in Asian patients with central precocious puberty. Hum Genome Var 2019;6:7.

111. Ghaemi N, Ghahraman M, Noroozi Asl S, Vakili R, Fardi Golyan F, Moghbeli M, et al. Novel DNA variation of GPR54 gene in familial central precocious puberty. Ital J Pediatr 2019;45:10.

112. Yi BR, Kim HJ, Park HS, Cho YJ, Kim JY, Yee J, et al. Association between MKRN3 and LIN28B polymorphisms and precocious puberty. BMC Genet 2018;19:47.

113. Jeong HR, Lee HS, Hwang JS. LHCGR gene analysis in girls with nonclassic central precocious puberty. Exp Clin Endocrinol Diabetes 2019; 127:234-9.
114. Jeong HR, Lee HS, Hwang JS. Makorin ring finger 3 gene analysis in Koreans with familial precocious puberty. J Pediatr Endocrinol Metab 2017;30:1197-201.

115. Grandone A, Capristo C, Cirillo G, Sasso M, Umano GR, Mariani M, et al. Molecular screening of MKRN3, DLK1, and KCNK9 genes in girls with idiopathic central precocious puberty. Horm Res Paediatr 2017;88:194-200.

116. Chen YC, Chen LM, Lin HH, Chen BH, Chao MC, Hsiao HP. Association study of LIN28B in girls with precocious puberty. J Pediatr Endocrinol Metab 2017;30:663-7.

117. Ortiz-Cabrera NV, Riveiro-Álvarez R, López-Martínez M, Pérez-Segura P, Aragón-Gómez I, Trujillo-Tiebas MJ, et al. Clinical pathogenic variants in familial and nonfamilial idiopathic central precocious puberty. Horm Res Paediatr 2017;87:88-94.

118. Simsek E, Demiral M, Ceylaner S, Kırel B. Two frameshift mutations in MKRN3 in Turkish patients with familial central precocious puberty. Horm Res Paediatr 2017;87:405-11.

119. Dimitrova-Mladenova MS, Stefanova EM, Glushkova M, Todorova AP, Todorov T, Konstantinova MM, et al. Males with paternally inherited MKRN3 mutations may be asymptomatic. J Pediatr 2016;179:263-5.

120. Hu Z, Chen R, Cai C. Association of genetic polymorphisms around the LIN28B gene and idiopathic central precocious puberty risks among Chinese girls. Pediatr Res 2016;80:521-5.

How to cite this article: Shim YS, Lee HS, Hwang JS. Genetic factors in precocious puberty. Clin Exp Pediatr 2022;65:172-81. https://doi.org/10.3345/cep.2021.00521 